\title{
Electrochemical Study of Breast Cancer Cells MCF-7 and Its Application in Evaluating the Effect of Diosgenin
}

\author{
Jia LI,* Xuanmin LIU,** Manli Guo,* Yingju LIU,* Shanchao LIU,* and Shouzhuo YAo*广 \\ * State Key Laboratory of Chemo/Biosensing and Chemometrics, College of Chemistry and Chemical Engineering, \\ Hunan University, Changsha 410082, P. R. China \\ **Institute of Life Science and Technology, Hunan University, Changsha 410082, P. R. China
}

\begin{abstract}
The electrochemical behavior of breast cancer cells was studied on a graphite electrode by cyclic voltammetry (CV) and potentiometric stripping analysis (PSA). In both cases, only one oxidative peak at approximately $+0.75 \mathrm{~V}$ was observed. The peak area in PSA was used to study the growth of the cells and the effect of diosgenin on MCF-7 cells. The results showed that diosgenin can effectively inhibit the viability and proliferation of the breast cancer cells.
\end{abstract}

(Received October 18, 2004; Accepted January 12, 2005)

Cell growth and the effect of some drugs on cells can be evaluated by traditional morphological observation methods or by biological technology. However, to perform these experiments, complex instruments and professionals are always required. Recent studies indicated that electrochemical methods, such as CV, scanning electrochemical microscopy, electric impedance and oxygen electrode, could also provide useful information on the living cell because the cell viability has positive relation with its electrode behavior. ${ }^{1-4}$

As a plant steroid produced by secondary metabolism, diosgenin shows many important biological functions in plants and animals, acting as a regulator of developmental and physiological processes in animal system. ${ }^{5}$ It is also widely used to synthesize new steroidal drugs. ${ }^{6}$ Recently, some studies have concerned its utilization in cancer therapy. ${ }^{7}$ However, to our knowledge, few reports about the effect of diosgenin on the breast cancer cells can be found in the literature.

Potential stripping analysis, first introduced by Jagner and Granile in 1976, is a highly sensitive electroanalysis technology including two steps: (1) preconcentration of the analyte by electrodeposition; and (2) stripping of the analyte by an appropriate oxidant. ${ }^{8}$ It has been applied to metal analysis and bioanalysis. ${ }^{9,10}$ In this work, electrochemical methods, i.e., potentiometric stripping analysis (PSA) and cyclic voltammetry $(\mathrm{CV})$, were used to investigate the electrochemical behavior of breast cancer cells and to evaluate the influence of diosgenin on the viability and proliferation of breast cancer cells. Trypan Blue dyeing tests were also employed to verify the results obtained by PSA.

\section{Experimental}

\section{Chemicals}

Diosgenin was from the Institute of Life Science and Technology of Hunan University. A stock solution of $1.0 \times 10^{-2}$

\footnotetext{
$\doteqdot$ To whom correspondence should be addressed.

E-mail: szyao@hnu.net.cn; ljac2002@hotmail.com
}

M diosgenin was prepared with ethanol and diluted to desired concentrations with water. Phosphate buffer solution (PBS) composed of $136.7 \mathrm{mM} \mathrm{NaCl}, 2.7 \mathrm{mM} \mathrm{KCl}, 9.7 \mathrm{mM} \mathrm{Na}_{2} \mathrm{HPO}_{4}$ and $1.5 \mathrm{mM} \mathrm{KH}_{2} \mathrm{PO}_{4}$ was used as the background electrolyte in all experiments. Other chemicals are of analytical grade.

\section{Instrumentation}

All electrochemical measurements were performed at a $\mathrm{CHI}$ 660A electrochemical analyzer (Chenhua Company, China) by applying a three-electrode system, with a graphite electrode $\left(0.45 \mathrm{~cm}^{2}\right)$ as working electrode, platinum as counter electrode and $\mathrm{Ag} / \mathrm{AgCl}$ electrode as reference electrode.

\section{Cell culture and cell treatment}

Breast cancer cell line MCF-7 was kindly provided by Dr. K. Q. Deng (Institute of Life Science and Technology of Hunan University) and was routinely cultured in RPMI-1640 medium (Invitrogen Corporation) $+10 \%$ fetal bovine serum (Sigma) + $0.05 \mathrm{mg} \mathrm{mL}^{-1}$ gentamicin (Sigma) $+100 \mathrm{U} \mathrm{mL}^{-1}$ penicillin (Sigma) at $37^{\circ} \mathrm{C}$ in a $\mathrm{CO}_{2}$ incubator containing $5 \% \mathrm{CO}_{2}$.

After the breast cancer cells were cultured for five days, they were collected by trypsinization with $0.05 \%$ (v/v) trypsin (Sigma) and centrifugation at $1200 \mathrm{rpm}$ for $10 \mathrm{~min}$, and then suspended in PBS. It should be mentioned that PBS-containing cells should be added to the detection chamber for electrochemical experiments immediately after the cell harvest. The density of the cells was determined by standard pour plate count (PPC) technique. For drug experiments, cells were allowed to grow and adhere for $24 \mathrm{~h}$ in culture medium before exposure to diosgenin. The same amount of alcohol was added to the control cells to eliminate the effect of ethanol on the breast cancer cells.

\section{Measurements}

Prior to each experiment, the graphite electrode was polished with fine emery paper and rinsed with water. Then it was put into the detection cell and treated by cyclic voltammetry between 0.0 and $1.0 \mathrm{~V}$ (vs. $\mathrm{Ag} / \mathrm{AgCl})$ until a stable voltammogram was obtained. After that, the fresh PBS 


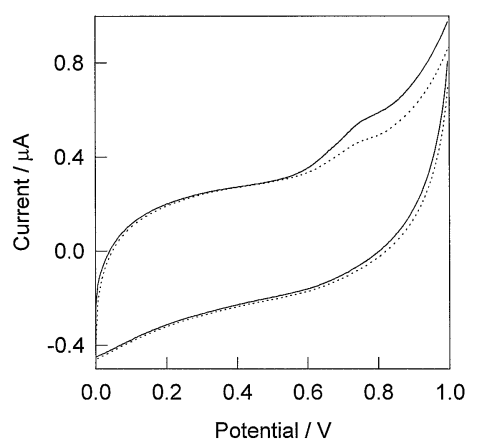

Fig. 1 Cyclic voltammograms of breast cancer cells in PBS at graphite electrode for the first cycle (solid line) and the second cycle (dashed line). Cell density, $4 \times 10^{5}$ cells $\mathrm{mL}^{-1}$; scan rate, $50 \mathrm{mV} \mathrm{s}^{-1}$.

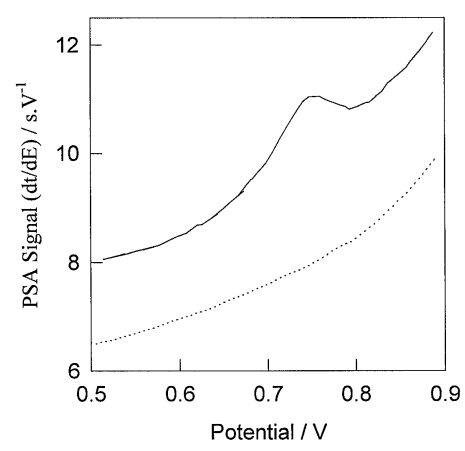

Fig. 2 PSA response of PBS in the presence of breast cancer cells (solid line) and in the absence of breast cancer cells (dashed line). Cell density, $4 \times 10^{5}$ cells $\mathrm{mL}^{-1}$; stripping current, $0.2 \mathrm{~mA}$; deposition potential, $0.0 \mathrm{~V}$; deposition time, $400 \mathrm{~s}$.

containing living cells was injected into the measuring chamber immediately. All electrochemical experiments were carried out at $37 \pm 1^{\circ} \mathrm{C}$. Morphological changes of the cell before and after exposure to diosgenin were observed with a Nikon Eclipse TE300 optical microscope (Japan).

\section{Trypan blue dye exclusion tests}

Cell viability in this work was determined by Trypan Blue dyeing experiment. The procedure was as follows: cells were seeded in 96-well plates at a density of 1500 cells/well. Trypan Blue (4\%) with a volume ratio of 1:10 was added to the cell solution. Experiments were replicated for five times. The following equation was used to calculate the cell viability:

$$
\text { Relative activity [\%] }=\left(N_{\text {tot }}-N_{\text {blue }}\right) / N_{\text {tot }}
$$

where $N_{\text {tot }}$ and $N_{\text {blue }}$ are the cell number in total and in blue, respectively.

\section{Results and Discussion}

PSA and CV response of MCF-7 cells

No redox peaks were observed at the polished graphite electrode between $0.0-1.0 \mathrm{~V}$ in PBS and in the culture medium, whether it contained cell metabolites or not. The cyclic voltammogram of breast cancer cells in PBS is shown in Fig. 1. As can be seen, an oxidative peak at around $+0.75 \mathrm{~V}$ is observed at a scan rate of $50 \mathrm{mV} \mathrm{s}^{-1}$, while no reductive peak is



Fig. 3 PSA response course of breast cancer cells in culture medium. After adherence for $24 \mathrm{~h}$, the seeding medium was removed and some fresh culture medium was added. Stripping current, 0.2 $\mathrm{mA}$; deposition potential, $0.0 \mathrm{~V}$; deposition time, $400 \mathrm{~s}$.

observed under the same condition. Furthermore, the anodic peak current decreases distinctly after the first cycle. Figure 2 shows the PSA responses of the electrode in PBS with the breast cancer cells or without them. An obvious peak at +0.75 $\mathrm{V}$ with a relative standard deviation of $5.4 \%(n=4)$ is observed when the cells are added to the PBS, but no peak is found in the blank solution. Therefore, the breast cancer cells exhibit an irreversible electrode behavior, similar to the tumor cell U937. ${ }^{11}$ Comparing Fig. 1 with Fig. 2, one can also find that PSA can generate more obvious response than $\mathrm{CV}$ under the same cell density.

The reason for the irreversible response may be as follows: firstly, some enzymes in the living cells assist in the unidirectional electron transfer process; ${ }^{12}$ secondly, formation and generation of coenzymes are also responsible for electron transfer between living cells and graphite electrode. ${ }^{1}$ Although our research indicated that DNA can generate a PSA signal at around $0.8-0.9 \mathrm{~V},{ }^{13}$ oxidation of DNA located in the karyon is difficult. In our experiments, neither CV nor PSA signal was found in culture medium containing cell metabolites after harvesting the cells (data not shown), which indicated that cell metabolites could not generate any electrochemical signal and that no detectable electrochemical active substances were released from the cells. Therefore, it is reasonable to estimate that the oxidation of coenzyme A bound to the cell wall is associated with the CV and PSA signals of MCF-7 cells as well as of other animal cells. ${ }^{14}$

\section{Optimization of PSA experimental conditions}

The parameters of PSA were optimized in detail. It is interesting to note that no obvious peak between $0.70-0.80 \mathrm{~V}$ was observed when the accumulation time was less than $200 \mathrm{~s}$, while the peak height did not increase any more if the time was longer than $400 \mathrm{~s}$. Therefore a deposition time of $400 \mathrm{~s}$ was selected. To choose an appropriate stripping current, we examined $0.05,0.1,0.2$, and $0.3 \mathrm{~mA}$. When the stripping current was lower than $0.2 \mathrm{~mA}$, the curves were unstable. When the stripping current was higher than $0.3 \mathrm{~mA}$, the stripping time was so short that no obvious signal could be found. Therefore, $0.2 \mathrm{~mA}$ was selected as the optimal stripping current. The deposition potential of $-0.2,0.0,0.2,0.4$, and 0.6 $\mathrm{V}$ was investigated. When living cells are stimulated by electricity, their physiological activity will change dramatically. ${ }^{15}$ To keep the living cell's viability during accumulation period, the $0.0 \mathrm{~V}$ value is preferred. 


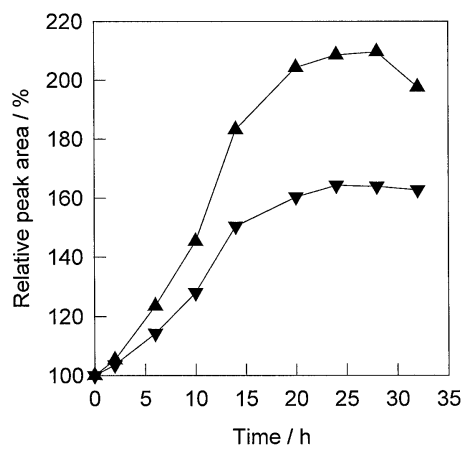

Fig. 4 Influence of diosgenin on the growth of the breast cancer cells. After adherence for $24 \mathrm{~h}$, the seeding medium was removed and fresh culture medium with diosgenin was added. Final concentration, $40 \mu \mathrm{M}$. $\boldsymbol{\Delta}$, Control group; $\boldsymbol{\nabla}$, experiment group. Experimental conditions as in Fig. 3.

\section{Monitoring cell growth by PSA}

PSA experiments were conducted to determine the cell viability when the breast cancer cells grew for different time periods. A series of cultures were prepared under the identical conditions and MCF-7 cells with the same density were added to the culture plates. Firstly, cells were allowed to grow for 24 $\mathrm{h}$ to adhere, and then the seeding medium was removed. During the cell culture course, nutrient was supplemented only once. At a specific time of cell culture, cells were harvested as mentioned above and the signal of PSA was recorded. The initial time was recorded when the fresh culture medium was added. The relative peak area of PSA response was used to reflect the growth status of the cells. The corresponding results are shown in Fig. 3 (seeding cell number was $4 \times 10^{5}$ cells $\mathrm{mL}^{-1}$ ). At first, the peak area is relatively low because metabolism level of the cells is low when the fresh nutrient is supplemented. However, it increases gradually with culture time until the highest level is reached after $20 \mathrm{~h}$; then it is maintained for another $8 \mathrm{~h}$. Afterwards, it decreases gradually due to the lack of nutrient, indicating that some part of the cells lose viability and the proliferation of the cells is inhibited. This can be confirmed by the fact that more and more cells became blue in Trypan Blue dying experiments if no fresh nutrient was supplemented after $24 \mathrm{~h}$.

\section{Evaluating the effect of diosgenin}

Living breast cancer cells can give PSA response under electrical stimulation and the response can reflect the viability of the cells. If the cells lost their viability, e.g. through lack of nutrient, the PSA response decreased correspondingly. Diosgenin, as a new natural anti-cancer drug, can also affect the viability of MCF-7 cells. Therefore, PSA can be used to evaluate the effect of diosgenin on MCF-7 cells. Figure 4 shows the PSA response of MCF-7 cells after its exposure to diosgenin. It can be seen that the electrochemical behavior of the cells begins to be affected after $2 \mathrm{~h}$. Remarkable change of the peak area are observed at $24 \mathrm{~h}$. Afterwards, the effect of the diosgenin becomes stable and unvaried. Trypan Blue dye exclusive experiments were also conducted to verify these results. As in Fig. 5, with the increase in the diosgenin concentration and exposure time, more harmful effects on the viability of MCF-7 cells are observed. The relative standard deviations in cell number counting were less than $8 \%(n=5)$.

The PSA can also be used to quantify the effect of diosgenin concentration on MCF-7 cells as follows:

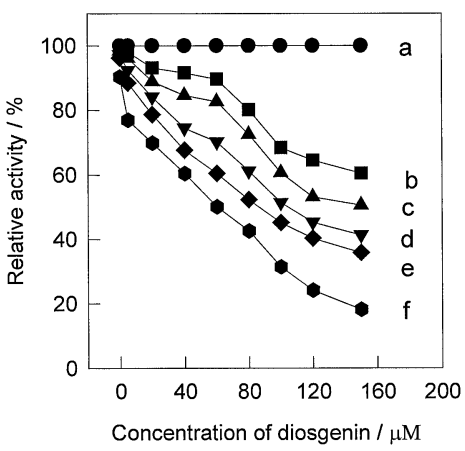

Fig. 5 Trypan Blue dye exclusive experiment for evaluating the effectiveness of diosgenin on breast cancer cells. From top to bottom, the lines a, b, c, d, e, and f represent the culture times of 0,2 , $6,14,24$, and $32 \mathrm{~h}$, respectively. After diosgenin was added, no fresh nutrient was supplemented.

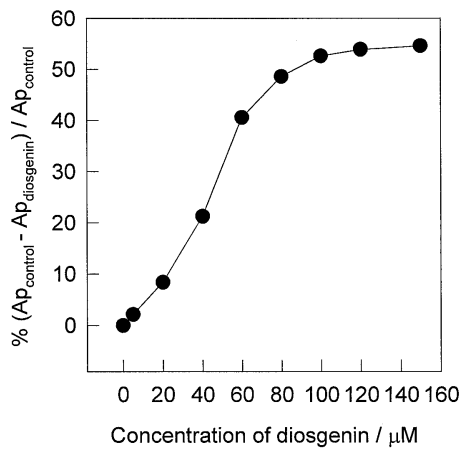

Fig. 6 Effect of diosgenin with different concentrations on breast cancer cells. The time for the cell culture with diosgenin was $24 \mathrm{~h}$ and the initial cell number was $4 \times 10^{5}$ cells $\mathrm{mL}^{-1}$. Experimental conditions as in Fig. 3.

$$
\text { Effect of diosgenin }=100 \% \times\left(A p_{\text {control }}-A p_{\text {diosgenin }}\right) / A p_{\text {control }}
$$

where $A p_{\text {diosgenin }}$ and $A p_{\text {control }}$ represent the peak areas of PSA of MCF-7 cells treated with and without diosgenin, respectively. Figure 6 shows the effect of diosgenin concentration on the PSA signal of MCF-7 cells. These experiments were replicated with relative standard deviations of less than $7 \%(n=5)$. When diosgenin concentration was above $40 \mu \mathrm{M}$, its effect increased dramatically. However, no significant change was observed when the concentration of diosgenin was higher than $100 \mu \mathrm{M}$.

The cytotoxic effect of diosgenin on breast cancer cells was also confirmed by morphological observation. Figure 7 shows the images of the cell with or without $100 \mu \mathrm{M}$ diosgenin for $3 \mathrm{~h}$ or $24 \mathrm{~h}$. From Image 1a, after the cells are exposed to diosgenin for $3 \mathrm{~h}$, the cells begin to float in the culture medium and start to lose its ability to contact with each other. But no obvious changes are observed in the control cells without diosgenin (shown in Image $1 \mathrm{~b}$ ). When the breast cancer cell is exposed to diosgenin for a longer time, e.g. $24 \mathrm{~h}$, abnormal behavior of the cells takes place and the density of MCF-7 cells in culture plate declines dramatically (Image 2a). The results indicated that the growth status of MCF-7 cells can be greatly influenced by diosgenin

In this work, the breast cancer cells MCF-7 were found to generate a PSA signal on graphite electrode. The effect of diosgenin on the breast cancer cells was also successfully 

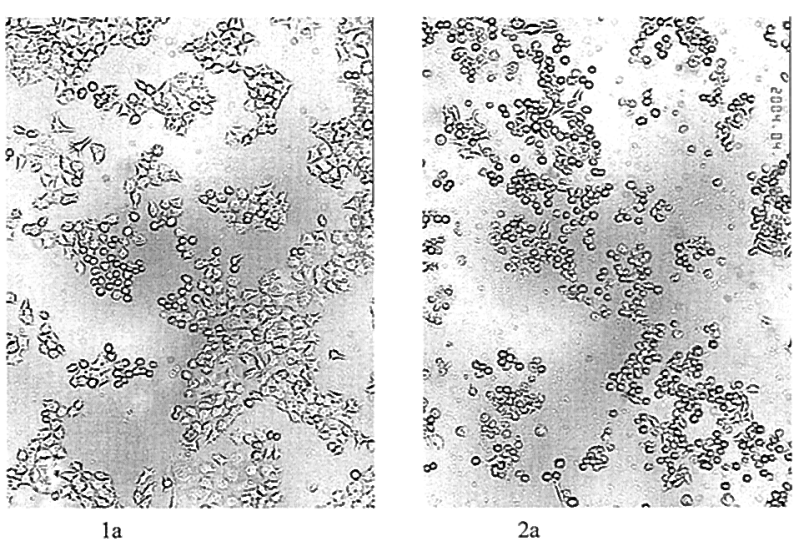

$2 \mathrm{a}$

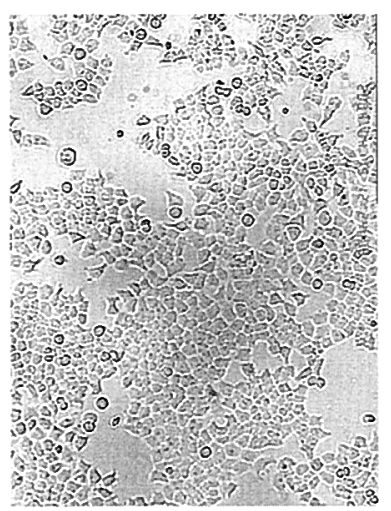

$1 \mathrm{~b}$

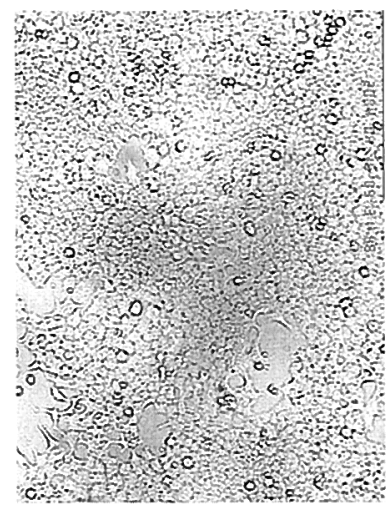

$2 b$

Fig. 7 Microscope images of breast cancer cells exposed to 100.0 $\mu \mathrm{M}$ diosgenin $(1 \mathrm{a}, 2 \mathrm{a})$ and $0.0 \mu \mathrm{M}$ diosgenin $(1 \mathrm{~b}, 2 \mathrm{~b})$ for $3 \mathrm{~h}(1 \mathrm{a}, 1 \mathrm{~b})$ and $24 \mathrm{~h}(2 \mathrm{a}, 2 \mathrm{~b})(200 \times)$.

evaluated by PSA and morphological observation. Therefore, PSA may be a simple electrochemical method to quickly evaluate the effectiveness of chemicals on cells in vitro.

\section{Acknowledgements}

We are grateful to Dr. K. Q. Deng for providing the breast cancer cell line. This work was supported by Key Project (No. 20335020) of the National Natural Science Foundation of China.

\section{References}

1. T. Matsunaga and Y. Namba, Anal. Chem., 1984, 56, 798.

2. B. Liu, S. A. Rotenberg, and M. V. Mirkin, Anal. Chem., 2002, 74, 6340.

3. C. D. Xiao, B. Lachance, G. Sunahara, and J. H. T. Luong, Anal. Chem., 2002, 74, 5478.

4. M. C. Sousa and J. P. Silva, Toxicol. in Vitro, 2001, 15, 297.

5. P. W. Becraft, Trends Genet., 2001, 17, 60.

6. H. Myszka, D. Bednarczyk, M. Najder, and W. Kaca, Carbohyd. Res., 2003, 338, 133.

7. S. Moalic, B. Liagre, C. Corbiere, A. Bianchi, M. Dauca, K. Bordji, and J. L. Beneytout, FEBS Lett., 2001, 506, 225.

8. D. Jagner and A. Graneli, Anal. Chim. Acta, 1976, 83, 19.

9. Y. Bai, X. Y. Ruan, J. Y. Mo, and Y. Q. Xie, Anal. Chim. Acta, 1998, 373, 39.

10. J. Wang, O. Rincon, R. Polsky, and E. Dominguez, Electrochem. Commun., 2003, 5, 83 .

11. J. Feng, G. A. Luo, H. Y. Jian, R. G. Wang, and C. C. An, Electroanalysis, 2000, 12, 513

12. A. Sucheta, B. A. C. Ackrell, B. Cochran, and F. A. Armstrong, Nature, 1992, 356, 361.

13. Y. J. Liu, K. Q. Deng, J. Li, S. C. Liu, and S. Z. Yao, Biophys. Chem., 2004, 112, 69.

14. T. Matsunaga, A. Shigematsu, and N. Nakamura, Anal. Chem., 1989, 61, 2471.

15. P. M. Ghosh, C. R. Keese, and I. Giaever, Biophys. J., 1991, 64, 602 . 